\title{
THE NOTIONS OF ENGLISH LANGUAGE AND RESEARCH INSTRUCTORS ON THE IMPACT OF DIGITAL TECHNOLOGIES ON THE RESEARCH WRITING PROCESS OF THEIR COLLEGE STUDENTS
}

\author{
Yvonne P. Velasco \\ Mary Ann V. Dolor \\ Carlos Hilado Memorial State College, Philippines \\ Email: yvonnevelasco@outlook.com
}

\begin{abstract}
APA Citation: Velasco, Y.P., \& Dolor, M. A. V. (2016). The notions of English language and research instructors on the impact of digital technologies on the research writing process of their college students. English Review: Journal of English Education, 5(1), 89-100
\end{abstract}

Received: 09-10-2016

Accepted: 09-11-2016

Published: 01-12-2016

\begin{abstract}
This is a descriptive study investigating teachers' view on the impact of digital technologies on the research writing of their students. Using Mishra and Koehler's (2006) TPCK model as framework, a probe was made on how technology and content are related and how pedagogical strategies in research relates to the use of technology in the classroom. The results reveal that teachers generally viewed the impact of digital technologies as positive but also showed misgivings on some aspects of technology use. The results have significant impact on the ICT policy currently being implemented in most state-run schools in the Philippines.

Keywords: digital technologies, teacher perceptions, college research, ICT policy
\end{abstract}

\section{INTRODUCTION}

The use of digital technologies in and for education is rapidly expanding in many countries and is now seen as both a necessity and an opportunity for improving and enhancing the education offered to citizens across the globe (UNESCO, 2006). In fact, Information and Communication Technology is regarded as a building block of modern society (UNESCO, 2002). Hence, the acquisition of skills in using digital technologies, generally labelled as Information and Communication Technology (ICT), has been regarded as part of their core education (UNESCO, 2002) by many countries globally. For example, in the United Kingdom, the official view of ICT as potentially transformative of education has placed it at the centre of the national agenda for school reform (Deaney, Ruthven, \& Hennessy, 2005). In the US, in its Informational Literacy Competency Standards for Higher Education, informational literacy is identified as crucial to today's environment of rapid technological change and proliferating information resources. All these are, undoubtedly, a collective global stance that supports the use of digital technologies in education, by especially focusing on the way students write in today's digital age.

As it is, the Philippines as a developing country makes efforts in recognizing the advances in communication due to technology and the internet, prompting the Department of Budget (DBM) and the Commission 
on Higher Education (CHED) to issue Joint Circular No. 1 (series of 2012), which establishes the guidelines on State Universities and Colleges (SUCs) on how to avail a portion of the Five Hundred Million Pesos (500,000,000.00php) allotted budgetary support for the maintenance, operating and other expenses (MOOE) and capital outlay (CO) requirements of selected SUCs (eligible under said guidelines) to undertake programs/projects and activities that will create key employment generators in the Priority Growth Sectors. In addition to this requirement for special funding, Article 2.3.d of the circular stipulates that as one of the criteria for selection of SUCs recipients,

$$
\text { ..."the SUCs mandated to offer }
$$
science and technology degree programs and those with good track record in their engineering, technology or ICT courses shall be given preference."

Paglaum State College (PSC), a government-owned higher education institution in the Philippines, does not need to prove its track record in engineering for it has consistently been in the category of Best Performing Schools in the Civil Engineering Board Examinations in the Philippines for the past 5 years since the inception of said course. What it needs is to prove that it deserves the budgetary support from DBM and CHED which requires establishing a good track record in its ICT courses. To this end, the PSC administration mandated the use of digital technologies in classroom instruction veering towards blended learning even.

This recent events in PSC, however, raises some concern in the sense that while the goal to improve ICT instruction is clear, the implementation of such initiative across departments and, ultimately, across PSC's four campuses is rather sketchy. While there seems to be no resistance being offered against PSC administration's initiative to integrate ICT in classrooms, no inquiry has been made about the teachers' comfort level in the use of these technologies in their classroom activities. Since teachers are facilitators of student success and achievement, their perceptions of, and attitudes toward, technology in education may be closely related to students' engagement with technology (Hadley, Eisenwine, Hakes, \& Hines, 2002). Considering that the expertise of teachers makes their role central to education, teachers' perceptions regarding technology integration may influence students' learning by constituting a part of a hidden curriculum (Fleener, 2002). Following Willis (1991), if perception is primary to human experience, then an investigation of teachers' perceptions of technology in education may serve to fill this seemingly neglected but very important area related to pedagogy in the $21^{\text {st }}$ century.

The central position of the teacher, between the school administration and the students, makes the teacher ultimately responsible for the successful implementation of policies of curriculum. Consequently, as enactors of the curriculum, teachers are the vital link between the curriculum planners and the students. Current literature suggests that teachers perceive computer technology primarily as a teacher aid to clerical work in basic word processing, calculating, keeping grades, and maintaining class rolls (Swan, et al., 2002; Swan, Bowman, Holmes, Vargas, \& Richardson, 2000). What this means is that these teachers look at technology as productivity tools and not as students' learning tools. This may have stemmed 
from the way teachers regard their ability to meet the challenges of technology integration since the literature indicates that many teachers feel inadequately prepared for this undertaking (McCannon \& Crews, 2000; Smerdon \& Cronen, 2000). Pinar and Irwin (2005) have cited this lack of technology training for teachers to carry serious implications for the relationship of human beings and computer technology. Over the past decade, technology has appeared in the classroom with increasing frequency and has become a major factor in education reform (Wenglinsky, 2000). However, even if more technology appears in the schools with each passing year and with each technological innovation, teachers are not using it effectively (Mackenzie, 1999; Padgett \& Conceicao-Runlee, 2000; Roblyer \& Edwards, 2000). Essentially, the teachers' perceptions about technology use may be used as a signpost that should indicate which way reform should proceed.

Balanskat et al. (2006) conducted a review of seventeen impact studies carried out between 2002 and 2006 which aimed at determining the benefits and impact of ICT integration in schools in two major areas: learning outcomes and learners, and teaching methodologies and teachers. The studies reveal some evidences that ICT impacts learner performance (Machin) as cited in Balanskat et al. (2006). Sutherland et al. (2004) reported on the findings of the Inter Active Education Project conducted in the United Kingdom, wherein teachers and researchers worked together to develop and evaluate initiatives focused on using ICT to enhance learning in curriculum areas that students would normally find difficulty in. The results show that despite the guardedness to use technology in the classroom, some teachers who participated in the project reported several positive outcomes with regards to ICT integration in the projects implemented. The teachers reported marked improvements in the writing skills of lower ability students, increased levels of interaction among students, greater student enthusiasm and engagement and an increase in confidence for both the teacher and the students.

Several researchers have argued that teacher beliefs about teaching and how students acquire knowledge play a critical role in determining not only the degree to which technology is used in the classroom but how technology is used to support teaching and learning. The sociocultural theory of learning posits that learning is interactive, discursive, technology-mediated, and situated (Schellens et al., 2005; Gee, 2003). Gee (2003) extends this perspective to suggest that human learning is "fully embedded in a material, social, and cultural world" (p. 8) and that the affordances of tools and technologies (e.g. computer and the Internet) can enhance learning. Furthermore, teachers' perceived usefulness of an innovation play a pivotal role in determining the extent to which that innovation will be adopted for use in the classroom (Hall \& Hord, 2001). However, Liu (2010) found that while teachers held learner-centered beliefs, they did not integrate constructivist teaching with technology use, thus revealing clear inconsistencies between teacher pedagogical beliefs and teaching activities. He found that most teachers, regardless of pedagogical beliefs, were inclined to utilize lecturebased instruction.

According to a report released by the Project Information Literacy, college students in the United States do not know how to do research correctly 
(www.huffingtonpost.com). The study, which surveyed 8.353 students from 25 colleges across the USA, reports that $84 \%$ of respondents found "getting started" to be the hardest part of research projects. Interestingly, if these are problems confronting college students in a first world country such as the United States, how would college students in a developing country such as the Philippines fare in their research activities especially since it was only recently that state-run higher institutions are catching on with teaching in digital space.

This study is informed by Mishra and Koehler's (2006) teaching with technology model. They theorize that well thought-out pedagogical uses of technology necessitate the development of a complex situated form of knowledge. This knowledge is what they refer to as Technological Pedagogical and Content Knowledge (TPCK). TPCK builds on Shulman's (1986) pedagogical content knowledge model, which outlines the essential qualities of teacher's knowledge required for effective integration of technology in teaching. TPCK is an emergent knowledge that goes beyond the three individual components of content, pedagogy, and technology and represents a class of knowledge that is central to teachers' work with technology. Hence, TPCK is an allencompassing theory on teaching technology that takes into account the teachers' appreciation of the digital phenomenon; this appreciation transcends knowledge of content, pedagogy, and of technology itself. Most initiatives in technology seemed fixated in the purchase of hardware (computers) for schools. It seems that there is an assumption that computers would magically transform teaching and learning. Even in cases where educational software was provided along with the hardware, there was the belief that knowledge was somehow embedded in the software and the technology (Sutherland, et al., 2004). However, knowing how to use technology is not to be construed with knowing how to teach with it. Teaching in the $21^{\text {st }}$ century therefore carries with it is not just practical knowledge, content, and strategies in teaching and integrating technology, but also an understanding of how all these are built up into a system that is compact and inseparable and requires the teachers' conscious effort to discern.

In an effort to understand the contexts and situations relating to the role played by teacher perceptions on the value of digital technologies to education particularly in research writing, this study sought to understand the English Language/ Research Instructors' perceptions of digital technologies and the importance of integrating ICT in the context of a mandate to integrate technology in the classrooms. Specifically, the following are the research questions addressed:

1. What is the English Language/Research Instructors' perception of the students' use of digital technologies for research paper writing, in terms of:

a. Manner (of doing research) b. Ability

2. What benefits may the various digital technologies bring in when utilized by the students in their research paper writing?

3. What risks can these digital technologies likely pose when utilized by the students in their research paper writing?

4. How do the English and Research Instructors view the impact of digital 
technologies on students' research writing?

\section{METHOD}

The study is descriptive and sought to understand the meanings teachers make of their experiences with digital technologies and the way it has impacted their students' research writing process. Merriam (1998) stresses that a descriptive study presents a detailed account of a phenomenon under study and is useful for investigating innovative programs and practices. Both the quantitative and qualitative methods were employed; the quantitative aspect is realised by conducting a survey while the qualitative aspect is realised by conducting a focus group discussion which stitched in the elements which a survey could not possibly uncover.

PSC has four campuses, hence, to have a comprehensive assessment of the English and Research instructors' perceptions the study included the possible maximum number of the population. However, due to some constraints, a $100 \%$ sampling of the population was not realized (Table 1 ).

Table 1. Participants distribution across four campuses

\begin{tabular}{ll}
\hline PSC Talisay & 20 \\
PSC Alijis & 15 \\
PSC Binalbagan & 15 \\
PSC Fortune Towne & 15 \\
\hline
\end{tabular}

The instrument used in this study was adapted from an online national survey conducted in the United States by Pew Internet, the College Board, and the National Writing Project. The survey is the Pew Research Center's Internet and American Life Project's first extensive examination of teachers' perceptions of the positive and negative impacts of a rapidly evolving technological environment on teachers' professional activities, and how that new environment has impacted teachers' own technology use (http:/ / pewinternet.org/Reports). The questionnaire is retrievable on-line and consisted of 50 items exclusive of the demographic assessment. While the questionnaire is divided into six sections, the researchers adapted the questions on the section relative to the impact of digital technologies on research, albeit, with some modifications to suit the culture and setting of the study.
Proper research conventions were observed (permissions, schedules, orientation as to the protocols for the conduct of the test, etc.) before the instrument was administered. The schedules for the focus group discussions proved a little problematic for the instructors' schedules would not allow for a common time schedule wherein they could convene without class disruption. The survey questionnaire administered prior to the FGD, the reason being that the issues which were not delved into in the survey can be further explored and clarified during the discussion that ensued. The FGD was audio-recorded and transcribed. The questionnaires were retrieved for scoring, statistical treatment, and interpretation.

Data analysis for the quantitative aspect consists of encoding the responses given by the participants in the survey questionnaire. The descriptive statistical 
mean and frequency measures were obtained to come up with a description of the area this study is concerned about. Data analysis for the qualitative aspect consists of a grounded theory approach (Strauss \& Corbin, 1990) such that data were analysed for emerging themes.

After the FGD sound file were transcribed, the data were segmented and re-grouped according to themes. Initial coding was done by examining the data and defining the ideas explicit within the data, and finally, categories were established. This method of analysis allowed for a rigorous review of the data culled from the FGD. Similarly, it provided for a structure for analysis and interpretation.

\section{RESULTS AND DISCUSSION}

Table 2 below presents the data regarding age and length of service.

Table 2. Distribution of Respondents in Terms of Age and Length of Service

\begin{tabular}{cccccc}
\hline Age & f & \% & Length & f & $\%$ \\
$20-29$ & 16 & 25 & $0-9$ & 16 & 25 \\
$30-39$ & 25 & 38 & $10-19$ & 29 & 46 \\
$40-49$ & 18 & 28 & $20-29$ & 15 & 23 \\
$50-59$ & 6 & 9 & $30-39$ & 5 & 8 \\
\hline
\end{tabular}

Table 2 shows that $38 \%$ of the participants belong to the 30-39 age bracket. This may imply that these participants have a relative exposure to digital technologies when they began school because the Internet saw its origins in the 1980 's. $46 \%$ have been teaching for more than 15 years (16-19- year bracket), while only $8 \%$ have been teaching for more than 30 years. More than half of the participants have been teaching for less than 20 years and considering this, the utility of being able to embed ICT in the classroom shall be felt more by this group of participants. Table 3 and 4 presents the demographics.

Table 3. Distribution of Respondents according to Gender and Home Internet

\begin{tabular}{cc}
\hline Gender & $\%$ \\
Male 18 & 28 \\
Female 47 & 72 \\
Home Internet & $\%$ \\
Yes - 30 & 46 \\
No - 35 & 54 \\
\hline
\end{tabular}

$72 \%$ of the participants are female while less than $50 \%$ of the participants have internet connections at home. This data gives us a picture of the teachers' access to the internet at home and to group the perceptions according to age and gender.

Table 4. Distribution of Respondents According to Digital Devices Owned

\begin{tabular}{|c|c|c|c|c|c|c|c|c|c|c|c|}
\hline \multicolumn{2}{|c|}{ Cellphone } & \multicolumn{2}{|c|}{ Smartphone } & \multicolumn{2}{|c|}{ Tablet } & \multicolumn{2}{|c|}{ Notebook } & \multicolumn{2}{|c|}{ Laptop } & \multicolumn{2}{|c|}{ Desktop } \\
\hline$f$ & $\%$ & f & $\%$ & f & $\%$ & f & $\%$ & f & $\%$ & f & $\%$ \\
\hline 55 & 85 & 18 & 28 & 27 & 42 & 48 & 74 & 40 & 62 & 43 & 66 \\
\hline
\end{tabular}

Evidently, most participants have cellphones, which implies that somehow, the importance of this digital device is felt across participants whether male or female, or whether tenured or not. 74\% of the participants have notebooks which 
gives the impression that they are positively endorsing the utility of digital technologies.

The participants of the study enthused that the definition of research has considerably changed in the digital world. This change according to them reflects how students approach the task of researching. Undeniably, search engines have a relative place in the world where students do research. Some participants said that for most of their students the idea of research is almost synonymous with 'Googling' the topics assigned. When prompted to elucidate on the matter, participants said that most of them felt that students would define the process as independently gathering information by looking it up or searching in Google. Furthermore, the participants expressed the perception that their students use only a handful of resources and rely mainly on search engines for their research. When asked how likely their students were to use a variety of different information sources for a typical research, $62 \%$ of the participants said their students were very likely to use Google or other online search engines. Table 5 presents the manner of sourcing/accessing information in the internet that the teachers perceive their students use.

Table 5. Manner of accessing information for research purposes

\begin{tabular}{cccccccccccc}
\hline Source & $\begin{array}{c}\text { Very } \\
\text { Likely }\end{array}$ & $\begin{array}{c}\text { Somewhat } \\
\text { Likely }\end{array}$ & $\%$ & $\begin{array}{c}\text { Not } \\
\text { Too } \\
\text { Likely }\end{array}$ & $\begin{array}{c}\text { Not } \\
\text { at } \\
\text { All }\end{array}$ & $\%$ Unsure & $\begin{array}{c}\text { Over- } \\
\text { all } \\
\text { Rating }\end{array}$ \\
\hline Google, etc & 40 & 62 & 14 & 22 & 4 & 6 & 1 & 2 & 6 & 9 & VL \\
\hline Online databases & 15 & 23 & 18 & 28 & 27 & 42 & 3 & 5 & 2 & 3 & NTL \\
\hline $\begin{array}{c}\text { E-mail; Yahoo, } \\
\text { Gmail }\end{array}$ & 24 & 37 & 30 & 46 & 7 & 11 & 4 & 6 & 0 & 0 & SL \\
\hline $\begin{array}{c}\text { Text books (print } \\
\text { or e-books) }\end{array}$ & 20 & 31 & 28 & 43 & 7 & 11 & 3 & 5 & 7 & 11 & SL \\
\hline $\begin{array}{c}\text { You tube or other } \\
\text { social media }\end{array}$ & 32 & 49 & 26 & 40 & 4 & 6 & 3 & 5 & 0 & 0 & VL \\
\hline $\begin{array}{c}\text { News sites } \\
\text { Nikipedia }\end{array}$ & 10 & 15 & 27 & 42 & 20 & 31 & 8 & 12 & 0 & 0 & SL \\
\hline & 40 & 62 & 20 & 31 & 3 & 5 & 2 & 3 & 0 & 0 & VL \\
\hline
\end{tabular}

Sixty-two percent $(62 \%)$ said their students were very likely to use Wikipedia or other online encyclopedias in a typical research assignment. Third on the list was YouTube or other social media sites, which about half of teachers $(52 \%)$ said their students were very likely to use. Only $31 \%$ think that the students are most likely to do research using textbooks or e-books. Based on these figures, it would appear that the use of textbooks has rather become passé with students when they do research. This finding has significance to the educational community in PSC in the sense that, an adequate library service would need to cater to how the students would conduct and write their research assignments. Simply stacking physical books in the library is no longer an option. The library should mirror the way students actually do research and as 
the findings of this study seem to imply, a huge measure of ICT capable tools are a need that must not be overlooked in the college library. Presently, there are only five (5) computer units in the library (main campus) that serve approximately two thousand $(2,000)$ students. This computer-to-student ratio is rather distressing.

A majority of survey respondents described their students as very good when it comes to understanding how online search results are generated and in their ability to use appropriate and effective search terms and queries. These likely reflect the participants' assessment of how well they have attained their instructional objectives in terms of these two skills. It is possible that the skills of doing online search, as well as using effective search queries are areas of instruction that were given emphasis by the participants and which reaped the positive approval ratings. Table 6 presents the results.

Table 6. Students ability to do on-line research

\begin{tabular}{|c|c|c|c|c|c|c|c|c|c|c|c|}
\hline Ability & 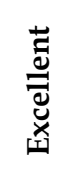 & $\%$ & 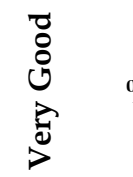 & $\%$ & : & $\%$ & 䒕 & $\%$ & $\stackrel{0}{0}$ & $\%$ & 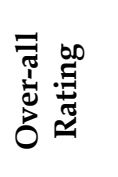 \\
\hline $\begin{array}{l}\text { Understanding online } \\
\text { results generation }\end{array}$ & 5 & 8 & 37 & 57 & 11 & 6 & 10 & 15 & 2 & 3 & VG \\
\hline $\begin{array}{l}\text { Using to use effective } \\
\text { terms and queries }\end{array}$ & 5 & 8 & 40 & 62 & 6 & 9 & 8 & 12 & 6 & 9 & VG \\
\hline $\begin{array}{l}\text { Assessing quality and } \\
\text { accuracy of information }\end{array}$ & 3 & 5 & 6 & 9 & 42 & 65 & 8 & 12 & 6 & 9 & G \\
\hline $\begin{array}{l}\text { Recognizing bias in } \\
\text { online content }\end{array}$ & 5 & 8 & 6 & 9 & 30 & 46 & 12 & 18 & 6 & 9 & G \\
\hline $\begin{array}{l}\text { Using multiple sources } \\
\text { to support argument }\end{array}$ & 4 & 6 & 4 & 6 & 38 & 58 & 14 & 22 & 5 & 8 & G \\
\hline $\begin{array}{l}\text { The survey in } \\
\text { research skills in part } \\
\text { participants consider } \\
\text { college students to le } \\
\text { survey constrained t } \\
\text { wherein participants } \\
\text { and very good ratings } \\
\text { FGD was able to extr } \\
\text { participants an exten } \\
\text { this particular topic. } \\
\text { were in agreement th } \\
\text { do online research, it } \\
\text { how to do online rese } \\
\text { knowing how to effe } \\
\text { and queries in the se } \\
\text { participant shared he } \\
\text { she was in the comp } \\
\text { one of her students ty }\end{array}$ & $\begin{array}{l}\text { ular } \\
\text { itic } \\
\text { n. T } \\
\text { cho } \\
\text { ave } \\
\text { stu } \\
\text { t fro } \\
\text { d d } \\
\text { te p } \\
\text { for } \\
\text { qui } \\
c^{\prime} \\
\text { vely }\end{array}$ & $\begin{array}{l}\mathrm{d} \\
\mathrm{d} \\
\mathrm{n} \\
\mathrm{s}\end{array}$ & $\begin{array}{l}\text { which } \\
\text { their } \\
\text { n the } \\
\text { five, } \\
\text { yood } \\
\text { the } \\
\text { ion on } \\
\text { ants } \\
\text { nts to } \\
\text { nowing } \\
\text { is, } \\
\text { erms } \\
\text { ea. One } \\
\text { e when } \\
\text { she saw } \\
\text { ble }\end{array}$ & & \multicolumn{7}{|c|}{$\begin{array}{l}\text { sentences in the search area. She said, "It } \\
\text { saddens me to see that student grappling } \\
\text { with technology at his fingertips. It was } \\
\text { supposed to make life easy for him, instead, it } \\
\text { made it a little complicated." } \\
\text { Accordingly, this has prompted } \\
\text { her to teach her students the skills of } \\
\text { finding information in the internet by } \\
\text { efficiently using search tools and } \\
\text { advance search, to which, most } \\
\text { participants favorably agreed. They were } \\
\text { also mostly unanimous in saying that the } \\
\text { skill in recognizing bias in online content } \\
\text { is quite difficult to teach, given that } \\
\text { students are always procrastinating and } \\
\text { would not be very discriminating with } \\
\text { content because of constraints in time. } \\
\text { "With technology, comes great } \\
\text { responsibility", quipped one participant }\end{array}$} \\
\hline
\end{tabular}


which elicited laughter from the group as this line is an allusion to the Spiderman movie. This statement however bears much truth when the findings from the survey came out. Risks and benefits indeed are equally present when using digital technologies in the research according to the participants. Table 7 shows the responses on the impact of digital technologies to students' research writing.

Table 7. Impact of digital technologies to students' research writing

\begin{tabular}{|c|c|c|c|c|c|c|c|c|c|c|c|}
\hline Impact & 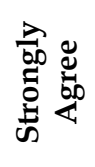 & $\%$ & 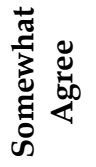 & $\%$ & ڤ્ & $\%$ & 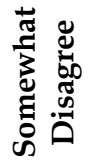 & $\%$ & 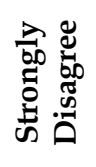 & $\%$ & 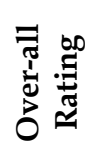 \\
\hline Overwhelming & 43 & 66 & 19 & 29 & 3 & 5 & 0 & 0 & 0 & 0 & SA \\
\hline $\begin{array}{l}\text { Quick and easy } \\
\text { information }\end{array}$ & 45 & 69 & 20 & 31 & 0 & 0 & 0 & 0 & 0 & 0 & SA \\
\hline $\begin{array}{l}\text { Availability of } \\
\text { resources }\end{array}$ & 50 & 77 & 12 & 18 & 3 & 5 & 0 & 0 & 0 & 0 & SA \\
\hline Self sufficiency & 15 & 23 & 42 & 65 & 6 & 4 & 4 & 6 & 0 & 0 & SWA \\
\hline $\begin{array}{l}\text { Discouraged use } \\
\text { of other sources }\end{array}$ & 12 & 18 & 45 & 69 & 1 & 2 & 4 & 6 & 3 & 5 & SWA \\
\hline $\begin{array}{l}\text { Harder to find } \\
\text { and use credible } \\
\text { sources }\end{array}$ & 14 & 22 & 34 & 52 & 6 & 9 & 5 & 8 & 6 & 9 & SWA \\
\hline
\end{tabular}

From among the benefits that merit the highest percentage (strongly agree) that has impact to students is availability of resources $(77 \%)$, second is that students find within their reach quick and easy to find information (69\%). 65\% somewhat agree that it fostered self-sufficiency among their students. For the risks, participants say that online information can be overwhelming (66\%) to students. They somewhat agree that digital technologies discouraged the use of other sources (69\%) and made it harder for students to find and use credible sources $(52 \%)$.

Overall, the survey and focus group findings suggest that instructors view the impact of the internet and digital technologies on the research process of their students positively. To the participants, the impact of the internet and digital tools on student research habits and skills is diverse. The focus groups afforded the instructors an opportunity to talk in more depth about the impacts they see the internet having on their students' research practices and among the benefits of these technologies, focus group participants noted how the internet provides students with greater breadth and volume of information than ever before. They held the belief that not only is more information more available now, but it is also available in many different formats. They said that this can benefit those students with different learning styles and even cognitive abilities. One instructor enthusiastically shared, "I just love the way they creatively include visuals to accompany their research! It implies that they are motivated to do the research assignment given to them."

When asked about what the instructors think the most positive 
impact digital technologies bring to the research endeavours of their students are, elicited varied responses. The coded responses relate to openness and accessibility of online information. They venture that students have quick access to some of the best available research online. Others expressed a sentiment that, "It's a pity PSC's library does not subscribe to online databases that could help a lot in our students' research undertaking."

Although this was countered by another when she mentioned that the internet also makes available to students quick access to online pornography. Another instructor commented, "The internet makes doing research for the students easier yet, because of the relative ease it affords them, it has led to procrastination and poor quality outputs."

According to them, the use of search engines beats researching using books, journals, etc, which is more tedious and more time-consuming for students.

The most negative aspect on the use of digital drew responses mainly concerning the ease by which students copy and paste information online. Likewise, concerns were raised about students' ability to judge the quality of online information. One participant mentioned that because of easy access to information, plagiarism has increased, "..and of course, there is online pornography which is an issue every school and home should address. The availability of firewalls should be disseminated to those parents who are not so well-versed about technology."

Furthermore, the participants mentioned that prior generations' research practices were time-consuming and that the learners of the digital age are fortunate to have the internet come to their aid in doing research. While doing research in the past entails seeking out relevant and accurate information from reliable sources, the students of today only need to 'google' the information. It is thus apparent that digital technologies has helped shape the way college students do research. By PSC's mandate of adopting ICT integration in the classrooms, comes this rather timely and opportune moment because the students, through the eyes of the English and Research instructors seem ready to adopt to this changing landscape of education.

In this study, the TPCK model was adopted by probing into teachers' perceptions to find out if there is an understanding of the interrelationship among the three types of knowledge that the TPCK model advances: what pedagogy is suitable for which content, how technology and content are related and how pedagogical strategies can be applied to the use of technology (Mishra \& Koehler, 2006). A clear picture of this understanding was initially gathered by getting the teachers' perceptions and it is discovered that indeed, ICT integration to the participants, is a reality that they must face. There is an utter lack of defining line whether teachers do realize that technology and content are related and, most importantly, with some admissions coming out during the FGD, that participants need further training for them to optimize the use of technology in the teaching learning process.

\section{CONCLUSION}

The survey and the FGD gave a glimpse of how English and Research instructors view the impact of digital technologies on the research writing of their students. It was generally viewed as positive, but there are also negative aspects perceived that teaching in digital spaces wrought. Teachers view that students are now in a position to do research tasks with an unlimited supply of information in their fingertips. This 
ENGLISH REVIEW: Journal of English Education Vol. 5, Issue 1, December 2016
ISSN 2301-7554

https://journal.uniku.ac.id/index.php/ERJEE boon to their research making is however seen as a bane too, in the sense that the unlimited supply of information can become overwhelming. Students need to be taught how to filter through vast amounts of information so that they are able to discriminate reliable and credible sources.

Though ICT integration is recognized by most institutions, there is no one-best-way or trajectory for elearning development at tertiary education institutions, and, it might prove more difficult to provide the social, organizational and legal changes in tertiary education than provide the technological infrastructures necessary to fully embrace the advantages of elearning (David, 2004). It is therefore quite necessary to include what the implementers (teachers) of ICT integration have to say and expose them to technology in multiple contexts in the earliest conceptions of the ICT initiatives of the school. Furthermore, there is a need for them to develop the kind of familiarity with digital technologies that foster confidence necessary to their willingness to use digital technologies in teaching. Indeed, according to Vasu and Atkins (2000), integration will succeed only if teachers are adequately trained to use the technology and if they also have adequate access to technology both at work and at home.

\section{REFERENCES}

Balanskat, A., Blamire, R., \& Kefala, S. (2006). The ICT Impact report: A Review of Studies of ICT impact on schools in Europe. European Schoolnet.

Civil Engineering Board Examinations. (2013). (retrieved on August 14, 2013 from www.chmsc.com.ph)

David, P. A (2004), Toward a Cyber infrastructure from Enhanced Scientific. Internet Institute.
Deaney, R., Ruthven, K., \& Hennessy, S. (2005). Teachers' developing practical theories of the contribution of information and communication technologies to subject teaching and learning: an analysis of cases from English secondary schools. British Educational Research Journal, 32(3), pp. 459-480.

Fleener, M. J. (2002). Curriculum dynamics: Recreating heart. New York: Peter Lang.

Gee, J. P. (2003). What video games have to teach us about learning and literacy, New York: Palgrave Macmillan.

Hadley, N., Eisenwine, M. J., Hakes, J. A., \& Hines, C. (2002). Technology infusion in the curriculum: Thinking outside the box. Curriculum and Teaching Dialogue 4(1), pp. 5-13.

Liu, S-H. (2010). Factors Related to Pedagogical Beliefs of Teachers and Technology Integration. Computers $\mathcal{E}$ Education (5)6, pp. 1012-1022.

Mackenzie, J. (1999). How teachers learn technology best. Bellingham WA: FNO Press.

McCannon, M., \& Crews, T. B. (2000). Assessing the technology training needs of elementary school teachers. Journal of Technology and Teacher Education, (8)2, pp. 111-121.

Mishra, P. \& Koehler, M.J. (2006). Technological Pedagogical Content Knowledge (TPCK): Confronting the Wicked Problems of Teaching with Technology. In R. Carlsen et al. (Eds.), Proceedings of Society for Information Technology \& Teacher Education International Conference 2007. Chesapeake, VA: AACE.

Padgett, D.L. \& Conceicao-Runlee, S. (2000). Designing a faculty development program on technology: If you build it, will they come? Journal of Social Work Education, 36(2), pp. 325-333.

Pinar, W. F., \& Irwin, R. L. (Eds.). (2005). Curriculum in a new key: The collected works of Ted Aoki. Mahwah, NJ: Lawrence Erlbaum.

Roblyer, M.D \& Edwards, J. (2000). Integrating educational technology into 
teaching. Upper Saddle River, New Jersey: Prentice - Hall.

Schellens, T., \& Valcke, M. (2006). Fostering knowledge construction in university students through asynchronous discussion groups. Computers and Education, 46, pp. 349-370.

Shulman, L. (1986). Those Who Understand: Knowledge Growth in Teaching. Educational Researcher, (15)2, pp. 4-14.

Smerdon, B., \& Cronen, S. (2000). Teachers' tools for the 21st century: A report on teachers' use of technology. Retrieved August 10, 2013 from http://nces.ed.gov

Strauss, A. \& Corbin, J. (1990). Basics of qualitative research: Grounded theory procedures and techniques. California: Sage Publications, Inc. Suther

Swan, K., Bowman, J.E., Jr., Holmes, A., Vargas, J.D., \& Richardson, J. (2000). Technology, professional development, and the culture of the schools. Paper presented at the annual meeting of the American educational Research Association, New Orleans.

Swan, K., Holmes, A., Vargas, J., Jennings, S., Meier, E., \& Rubenfeld, L., (2002). Situated professional development and technology integration: The CATIE mentoring program. Journal of Technology and Teacher Education, 10(2), pp. 169-190.
Sutherland, V. Armstrong, S. Barnes, R. Brawn, \& N.

Breeze, (2004).Transforming teaching and learning: embedding ICT into everyday classroom practices. Journal of Computer Assisted Learning, 20(6), [retrieved on August 13, 2013 from

http://www.tlrp.org/pub/documents /Sutherland_RB_19.pdf]

UNESCO. (2006). ICT in Education. (Retrieved August 12th, 2013 from http:// portal.unesco.org/ci/en/ev.php)

UNESCO. (2002). ICT in Education. (Retrieved August 13rd, 2013 from http:/ / portal.unesco.org/ci/en/ev.php)

Vasu, E. \& Atkins, N. (2000). Measuring Knowledge of Technology Usage and Stages of Concern about Computing: A Study of Middle School Teachers. Journal of Technology and Teacher Education, 8(4), pp. 279-302.

Wenglinsky, H. (2000). How teaching matters: bringing the classroom back into discussions of teacher quality. (Policy Information Center Report from the Milken Family Foundation and Educational Testing Service) Princeton, N.J.: Milken Foundation.

Willis, G. (1991). Phenomenological inquiry: Life-world perceptions. In E. C. Short (Ed.), Forms of Curriculum Inquiry. Albany: State University of New York Press. 